\title{
NGHIÊN CÚU ÚNG DỤNG MÔ HÌNH IFAS VÀ DŨ̉ LIỆU VIỄN THÁM TRONG MÔ PHỎNG DÒNG CHẢY LŨ XUYÊN BIÊN GIỚI LUUU VỰC SÔNG THAO
}

\author{
Bùi Tuấn Hải ${ }^{1}$, Lê Viết Sơn ${ }^{1}$
}

Tóm tắt: Nghiên cứu này ưng dụng kết hợp dũ liệu viễn thám và mô hình IFAS trong mô phỏng dòng chảy lũ xuyên biên giới lưu vục sông Thao với phần lớn luu vưc nằm ở phía Trung Quốc. Kết quả hiệu chỉnh và kiểm định mô hình IFAS cho trận lũ năm 2008 và 2016 chỉ ra rằng mô hình với số liệu đầu vào viễn thám có khả năng mô phỏng dòng chảy lũ khá tốt. Kết quả hiệu chỉnh mô hình IFAS trận lũ tháng $8 / 2008$ cho hệ số tuoong quan $R^{2}=0,887$, hệ số $N S E=0,813$; kêt quả kiểm định với trận lũ tháng 8/2016 cho hệ số $R^{2}=0,555$ và hệ số $N S E=0,547$. Kết quả hiệu chỉnh mô hình mô phỏng ngập lụt TP. Yên Bái và khu đông dân cu ven sông Thao bằng cách liên kết mô hình thủy lục 1 chiều MIKE11 và mô hình thủy lực 2 chiều MIKE21 cho kết quả với trận lũ tháng 8/2008 hệ số $R^{2}$ tại Yên Bái đạt 0,875; hiệu chinh với trận lũ 8/2016 hệ số $R^{2}$ tại Yên Bái đạt 0,624. Nghiên cúu cũng xây dựng bản đồ vùng nguy co ngập lụt tương ứng với kịch bản lũ lịch sử năm 2008 và 2016. Việc mô phỏng được một cách khá tốt dòng chảy lũ trên lưu vực sông Thao là tiền đề để dụ báo lũ cho hạ du sông Thao, nhằm phòng chống và giảm thiểu tác hại của lũ gây ra cho kinh tế - xã hội, đặc biệt khu vưc dân cu tập trung ven sông Thao.

Từ khóa: Sông Thao, Viễn thám, IFAS, GSMAP, MIKE11, MIKE21.

Ban Biên tập nhận bài: 2/04/2020 Ngày phản biện xong: 18/05/2020 Ngày đăng bài: 25/05/2020

\section{1. Đặt vấn đề}

Trong những năm gần đây công nghệ viễn thám đang được nghiên cứu ứng dụng rộng rãi trong hầu hết mọi lĩnh vực trong đó có quản lý tài nguyên nước. Một trong những thế mạnh của công nghệ viễn thám là cung cấp số liệu chi tiết và chính xác sự biến động của điều kiện tự nhiên và xã hội các lưu vực sông theo không gian và thời gian, không phân biệt đó là sông nội địa hay sông xuyên biên giới. Nghiên cứu sử dụng tài liệu viễn thám kết hợp với các công nghệ phù hợp trong dự báo khí tượng, thủy văn, dòng chảy và quản lý tài nguyên nước các lưu vực sông là một giải pháp hữu ích nhằm khắc phục tình trạng thiếu các tài liệu thực đo đang được nhiều nhà khoa học quan tâm. Hiện nay trên thế giới đã có khá nhiều nghiên cứu sử dụng dữ liệu viễn thám trong mô phỏng dòng chảy lũ, có thể kể đến nghiên cứu của Bates (2004) [1] ứng dụng viễn thám và mô phỏng ngập lụt và được tác giả bổ ${ }^{1}$ Viện Quy hoạch Thủy lợi Email: buituanhai@gmail.com sung kết quả nghiên cứu vào năm 2012 [2]. Ngoài ra, Klemas (2015) nghiên cứu tổng quan ứng dụng dữ liệu viễn thám vào dự báo vùng nguy cơ ngập lụt [3]. Tuy nhiên, việc ứng dụng viễn thám vào mô phỏng dòng chảy lũ xuyên biên giới còn chưa có nhiều nghiên cứu.

Lũ lụt là một loại thiên tai thường xuyên xảy ra ở nước ta nói chung và ở Bắc Bộ nói riêng đặc biệt là miền núi phía Bắc, nơi có địa hình, địa chất phức tạp gây ra những thiệt hại lớn về người và của. Đối với lưu vực sông Thao, trong những năm gần đây một số trận lũ lớn đã gây thiệt hại cho tỉnh Yên Bái như trận lũ tháng 8/2008, tháng $8 / 2016$ và trận lũ mới xảy ra năm trước vào tháng 7/2018 đã gây ảnh hưởng đến phát triển kinh tế - xã hội trên địa bàn tỉnh Yên Bái và các tỉnh lân cận [4]. Nghiên cứu dòng chảy lũ sông Thao, đánh giá tác động cũng như những thiệt hại của mưa lũ gây ra với đời sống kinh tế xã hội, từ đó có những phương pháp ứng phó với mưa lũ trong tương lai. Nghiên cứu quá trình hình thành 
dòng chảy lũ từ thượng nguồn sông Thao có ý nghĩa quan trọng đối với việc cảnh báo thiên tai cho khu vực hạ du. Tuy nhiên, lưu vực sông Thao có phần lớn diện tích lưu vực nằm ở Trung Quốc, nơi không có số liệu và thiếu các số liệu đầu vào cho tính toán.

Ở Việt Nam, hiện nay cũng đã có khá nhiều nghiên cứu sử dụng mô hình thủy văn phân bố, như nghiên cứu của Đoàn Quang Trí (2019) về mô hình MIKE SHE [5], nghiên cứu sử dụng mô hình thủy văn bán phân bố SWAT của các tác giả Trịnh Minh Ngọc (2009) trong tính toán kéo dài chuỗi dòng chảy [6] và nghiên cứu của Nguyễn Ý Như và Nguyễn Thanh Sơn (2009) về ảnh hưởng của biến đổi sử dụng đất đến dòng chảy [7]. Nghiên cứu về mô hình thủy văn phân bố IFAS kết hợp dữ liệu mưa vệ tinh có thể kể đến nghiên cứu của Lê Viết Sơn và cs (2019) trong nghiên cứu cho lũ lưu vực sông Đà [8], ngoài ra còn có nghiên cứu của Bùi Tuấn Hải và cs cho lũ thượng nguồn sông Cả về thủy điện Bản Vẽ [9]. Mặc dù đã có khá nhiều nghiên cứu về mô hình thủy văn phân bố, nhưng mô hình thủy văn phân bố IFAS hiện vẫn chưa được

nghiên cứu nhiều ở Việt Nam.

Để có thể mô phỏng tác động của dòng chảy lũ với hạ du, trong phạm vi nghiên cứu này tập trung đánh giá phạm vi ngập lụt trong hai trận lũ lịch sử tại thành phố Yên Bái là trận lũ năm 2008 và năm 2016. Tuy nhiên mô hình thủy văn mới chỉ cung cấp số liệu dòng chảy, để có thể mô phỏng ngập lụt hạ du thì cần phải kết hợp với bộ mô hình thủy lực, trong nghiên cứu này đề xuất sử dụng mô hình thủy lực 1 chiều MIKE11 kết hợp mô hình thủy lực 2 chiều MIKE21 với số liệu đầu vào từ mô hình thủy văn phân bố IFAS. Mục đích của nghiên cứu này: (1) Ứng dụng dữ liệu viễn thám làm đầu vào cho mô hình thủy văn phân bố IFAS; (2) Nghiên cứu ứng dụng mô hình thủy văn thông số phân bố IFAS tính toán lưu lượng đầu vào mô hình MIKE11; (3) Kết hợp mô hình MIKE11 và MIKE21 mô phỏng ngập lụt cho TP. Yên Bái và khu đông dân cư tập trung ven sông Thao.

\section{Dữ liệu, phương pháp và công cụ nghiên cứu}

\subsection{Giới thiệu khu vục nghiên cúu}

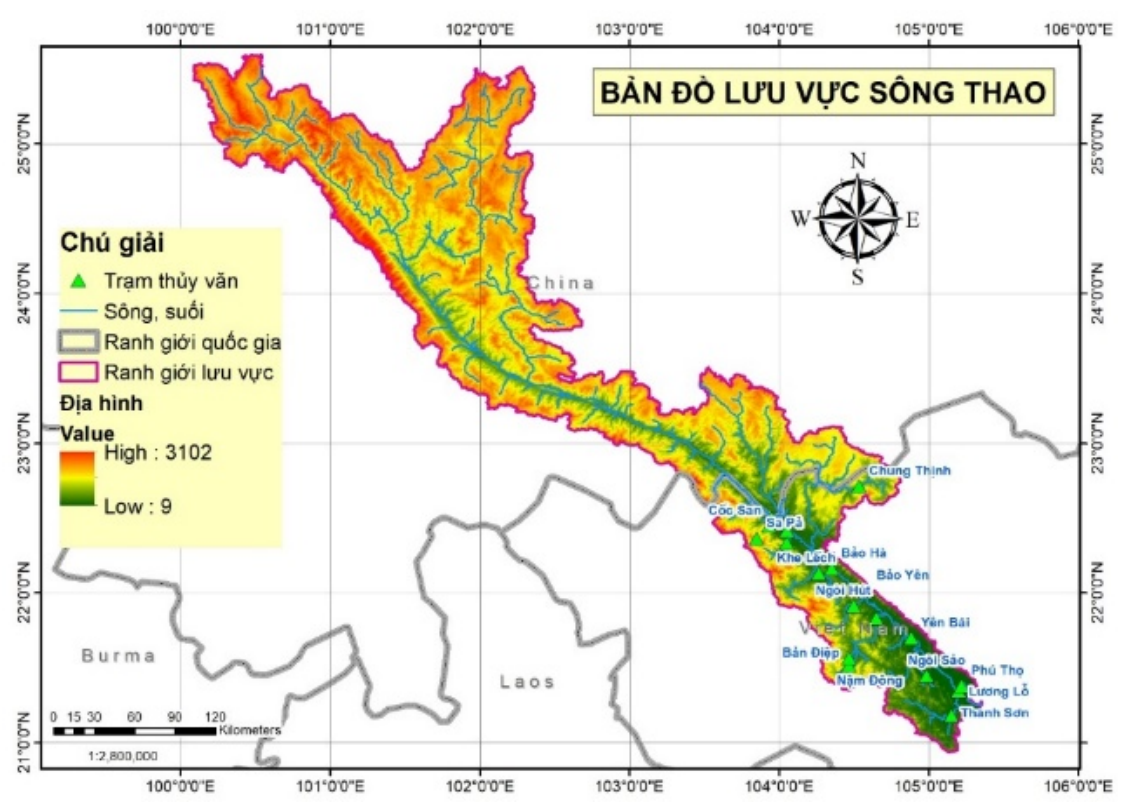

Hình 1. Bản đồ lưu vục sông Thao

Sông Thao là dòng chính của sông Hồng, bắt nguồn từ dãy núi Ngụy Sơn ở độ cao $1.776 \mathrm{~m}$ thuộc tỉnh Vân Nam, Trung Quốc, chảy theo hướng Tây Bắc - Đông Nam song song với sông
Đà. Chiều dài sông $843 \mathrm{~km}$, phần chảy qua địa phận Việt Nam là 332 km. Diện tích lưu vực sông Thao (tính đến Trung Hà) $51.800 \mathrm{~km}^{2}$ trong đó diện tích thuộc lãnh thổ Trung Quốc là 39.800 
$\mathrm{km}^{2}$ chiếm 77\%, diện tích tthuộc lãnh thổ Việt Nam $12.000 \mathrm{~km}^{2}$ chiếm 23\%. Tại Việt Nam, sông chảy qua các tỉnh Lào Cai, Yên Bái và Phú Thọ. Khi qua tỉnh Yên Bái, sông có bốn phụ lưu lớn là ngòi Thia, ngòi Hút, ngòi Lâu và ngòi Lao.

Phần hạ lưu vực sông Thao tuy lượng mưa gấp đôi nhưng diện tích nhỏ, dài hẹp nên mưa xảy ra không đồng đều và lũ trên lưu lưu vực cũng không đồng nhất. Lũ lớn sông Thao thường xảy ra từ tháng VII đến tháng IX, nhiều nhất vào tháng VIII, khoảng 41\% trường hợp ở Yên Bái. Trong thời gian này (tháng VII, VIII, IX) phía Trung Quốc, thời gian ngọn lũ xuất hiện ở Nguyên Giang gần như đồng thời với ngọn lũ ở trạm Lý Tiên Độ trên sông Lý Tiên Độ thuộc thượng lưu sông Đà. Phần hạ du sông Thao (từ biên giới Việt - Trung - Việt Trì) đã xảy ra lũ lớn nhất trong từng tháng và vào đầu và cuối mùa lũ do Front lạnh gây ra: 21/VI/1980, 7/IX/1986, 11/X/1986, 13/X/1983.
Gần bốn chục năm gần đây trên sông Thao ở Yên Bái đã xảy ra một số trận lũ lớn và đặc biệt lớn: năm 1980: $\mathrm{Q}_{\max }=6.840 \mathrm{~m}^{3} / \mathrm{s}$ và tháng VIII/1996: $Q_{\max }=5.990 \mathrm{~m}^{3} / \mathrm{s}$ và trận lũ lịch sử tháng VIII/2008 với $Q_{\max }$ đạt $10.800 \mathrm{~m}^{3} / \mathrm{s}$.

Một số dòng chảy lớn nhất thường giảm dần theo tỷ lệ nghịch với diện tích lưu vực. Mô dun dòng chảy trên dòng chính sông Thao với diện tích lưu vực 50.000 km² vẫn còn lớn (kém sông Đà và sông Lô), $M_{\max }=200-400 \mathrm{l} / \mathrm{s} / \mathrm{km}^{2}$, phần Việt Nam 200 1/s/km², phần Trung Quốc lớn gấp đôi, bằng $400 \mathrm{l} / \mathrm{s} / \mathrm{km}^{2}$.

Cường suất nước lên ở Lào Cai không lớn lắm, đạt $1,33 \mathrm{~m} /$ ngày nhưng do ảnh hưởng của lũ sông nhánh nên ở Yên Bái có cường suất lũ đạt $2,06 \mathrm{~m} /$ ngày. Ngược lại biên độ mực nước lớn nhất ở Lào Cai 13,20 m, Yên Bái 8,30 m.

Những trận lũ lớn nhất hàng năm của sông Thao tại Yên Bái có: $\mathrm{Q}_{\max } / \mathrm{Q}_{\mathrm{tb}}=2,08$ lần, $\mathrm{Q}_{\max } / \mathrm{Q}_{\min }=3,52$ lần, $\mathrm{C}_{\mathrm{v}}=0,36$ [10] [11].

Bảng 1. Đặc trưng nước lũ sông Thao

\begin{tabular}{|c|c|c|c|c|c|}
\hline \multirow{2}{*}{ Đặc trưng } & \multirow{2}{*}{ Đơn vị } & \multicolumn{4}{|c|}{ Trạm } \\
\hline & & Trung Quốc & Lào Cai & Yên Bái & Phú Thọ \\
\hline Khoảng cách đến cửa sông & $\mathrm{km}$ & 378 & 274 & 114 & 39 \\
\hline Diện tích lưu vực & $\mathrm{km}^{2}$ & 34.500 & 41.000 & 48.000 & 51.300 \\
\hline Thời kỳ quan trắc & & & 1956-1978, 1995-nay & 1902-nay & 1956-nay \\
\hline $\mathrm{Q}_{\max }$ bình quân & $\mathrm{m}^{3} / \mathrm{s}$ & & 3.550 & 5.180 & \\
\hline$Q_{\max }$ tháng X/1986 & $\mathrm{m}^{3} / \mathrm{s}$ & & & 7.510 & 6.200 \\
\hline Q $\max$ tháng VIII/1996 & $\mathrm{m}^{3} / \mathrm{s}$ & & 3.450 & 4.410 & \\
\hline $\mathrm{Q}_{\max }$ tháng VIII/2008 & $\mathrm{m}^{3} / \mathrm{s}$ & & 6.550 & 10.800 & \\
\hline $\mathrm{Q}_{\max } \mathrm{P}=1 \%$ & $\mathrm{~m}^{3} / \mathrm{s}$ & & 9.450 & 11.540 & \\
\hline Mô số đỉnh lũ max & $1 / \mathrm{s} \cdot \mathrm{km}^{2}$ & 391,3 & 206 & 225 & 210 \\
\hline Tổng lượng W8 ngày bình quân & $\mathrm{km}^{3}$ & & 1,58 & 2,12 & 2,41 \\
\hline
\end{tabular}

\subsection{Thu thập dĩ liệu nghiên cứu}

a) Số liệu mưa vệ tinh có độ bao phủ toàn cầu có khá nhiều với những đặc tính kỹ thuật khác nhau như độ phân giải về không gian, độ phân giải về thời gian. Các dữ liệu mưa vệ tinh GPM, GSMAP, CHIRPS, CMORPH được Bùi Tuấn Hải và Nguyễn Văn Tuấn (2018) [12] nghiên cứu, phân tích và so sánh với dữ liệu mưa thực đo. Kết quả nghiên cứu cho thấy mưa vệ tinh có khả năng nhận diện ngày mưa và không mưa khá tốt với mức độ chính xác đạt tới $70 \%$ số ngày; giữa tổng lượng mưa tháng thực đo và các dữ liệu mưa vệ tinh hệ số tương quan Pearson $\mathrm{R}$ đạt trung bình từ 0,79 đến 0,85 ; hệ số xác định $\mathrm{R}^{2}$ đạt trung bình từ 0,63 đến 0,76 . Nghiên cứu này sử dụng dữ liệu mưa GSMAP do nó có độ phân giải không gian cao 0,10 (khoảng $10 \mathrm{~km}$ ), độ phân giải về thời gian là một giờ, dữ liệu được cung cấp liên tục, độ trễ thấp so với các dữ liệu khác.

b) Độ cao địa hình cùng hướng dốc địa hình là những số liệu đầu vào quan trọng trong việc xác định hướng dòng chảy và phân lưu dòng chảy, phân các tiểu lưu vực, phân bố dòng chảy 
trong mô hình phân bố. Dư liệu mô hình số độ cao (DEM) toàn cầu là số liệu phổ biến trong nghiên cứu về địa hình. Kết quả nghiên cứu của Bùi Tuấn Hải và cs (2019) [13] về 03 dữ liệu của DEM là ALOS, ASTER và SRTM cho biết với độ cao từ $50 \mathrm{~m}$ trở lên các số liệu DEM toàn cầu thể hiện rất tốt địa hình, trong đó hệ số tương quan $\mathrm{R}^{2}$ giữa dữ liệu $\mathrm{DEM}$ toàn cầu và số liệu từ bản đồ địa hình tỷ lệ 1/50.000 đều cao hơn 0,98. Kết quả nghiên cứu cũng cho thấy dữ liệu ALOS tốt hơn ASTER và SRTM. Trong nghiên cứu này, dữ liệu ALOS sẽ được sử dụng đưa vào phân chia lưu vực, tiểu lưu vực và xác định hướng dòng chảy trong mô hình IFAS.

c) Một số dữ liệu toàn cầu khác cũng được sử dụng trong cung cấp số liệu đầu vào như số liệu lớp phủ bề mặt toàn cầu (GLCC) của Cơ quan Địa chất Hoa Kỳ (USGS) và Bản đồ số dữ liệu đất toàn thế giới (DSMW) của Tổ chức Lương thực và Nông nghiệp Liên Hiệp Quốc (FAO).

d) Để so sánh, đánh giá giữa số liệu thực đo và mô phỏng, trong nghiên cứu này đã sử dụng số liệu lưu lượng thực đo tại trạm Yên Bái trong hai trận lũ tháng 8/2008 và trận lũ tháng 8/2016.

\subsection{Giới thiệu mô hình IFAS}

Mô hình IFAS là tập hợp các bộ công cụ với giao diện đồ họa phục vụ cho việc xây dựng mô hình phân bố mưa - dòng chảy. Để kết hợp số liệu từ công nghệ viễn thám vào trong mô hình phục vụ tính toán dòng chảy trên lưu vực sông Thao, nghiên cứu này lựa chọn mô hình IFAS. Mô hình IFAS có lõi là mô hình thủy văn phân bố Public Works Research Institute Distributed Hydrological model (PWRI-DHM) [14] có khả năng tự động và nhanh chóng xử lý số liệu viễn thám đưa vào mô hình tính toán; còn công nghệ viễn thám có khả năng cung cấp số liệu theo không gian và thời gian. Cấu trúc của mô hình PWRI-DHM gồm các mô hình dạng bể chứa như sau:

- Mô hình bể chứa nước mặt (surface tank model): bao gồm các yếu tố dòng thấm vào tầng chưa bão hòa, dòng chảy bề mặt, khu trữ bề mặt, bốc thoát hơi nước, ...

- Mô hình bể chứa tầng chưa bão hòa (unsat- urated tank model): bao gồm các yếu tố dòng thấm xuống tầng ngầm, dòng chảy dưới lớp mặt, khu trữ dưới lớp mặt,...

- Mô hình bể chứa ngầm (aquifer tank model): bao gồm các yếu tố dòng chảy ra khỏi tầng nước ngầm, tổn thất dòng chảy ngầm.

- Mô hình bể chứa sông suối (river tank model): mô tả lưu lượng dòng chảy trong sông.

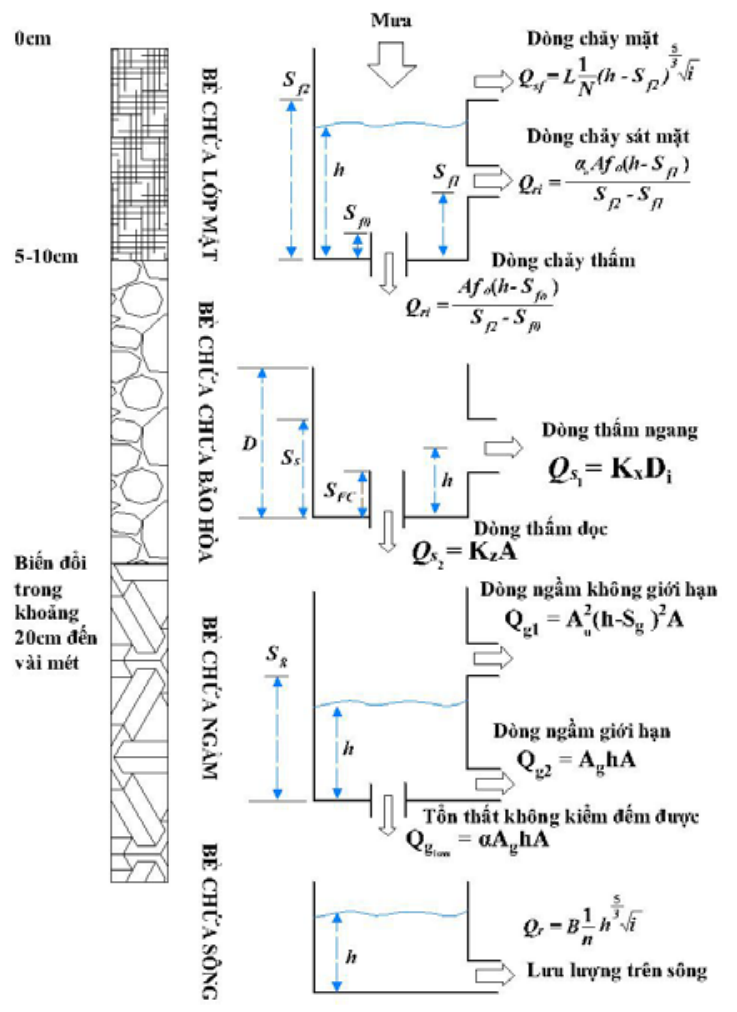

\section{Hình 2. So đồ nghiên cứu mô hình IFAS}

\subsection{Giới thiệu mô hình MIKE 11, MIKE 21}

Mô hình toán MIKE 11 do Viện Thủy lực Đan Mạch (DHI) phát triển đã được áp dụng cho việc đánh giá các đặc tính thủy lực của hệ thống sông Thao. MIKE 11 là một mô hình thuỷ động lực học một chiều dựa trên việc giải nghiệm của hệ phương trình St.Venant. MIKE 11 bao gồm nhiều mô đun có các khả năng và nhiệm vụ khác nhau như: mô đun mưa dòng chảy (RR), mô đun thuỷ động lực (HD), mô đun tải - khuếch tán (AD), mô đun sinh thái (Ecolab) và một số mô đun khác. Trong đó, mô đun thuỷ lực (HD) được coi là phần trung tâm của mô hình, tuy nhiên tuỳ theo mục đích tính toán mà chúng ta kết hợp sử dụng với các mô đun khác một cách hợp lý và 


\section{BÀI BÁO KHOA HỌC}

khoa học [15].

MIKE 21 FM là một mô hình hai chiều ứng dụng cho các khu vực cửa sông, vùng ngập lũ, vùng ven biển và ngoài khơi, được phát triển bởi Viện Thủy lực Đan Mạch (Denmark Hydraulic Institute). "FM" là viết tắt của từ "flexible mesh"
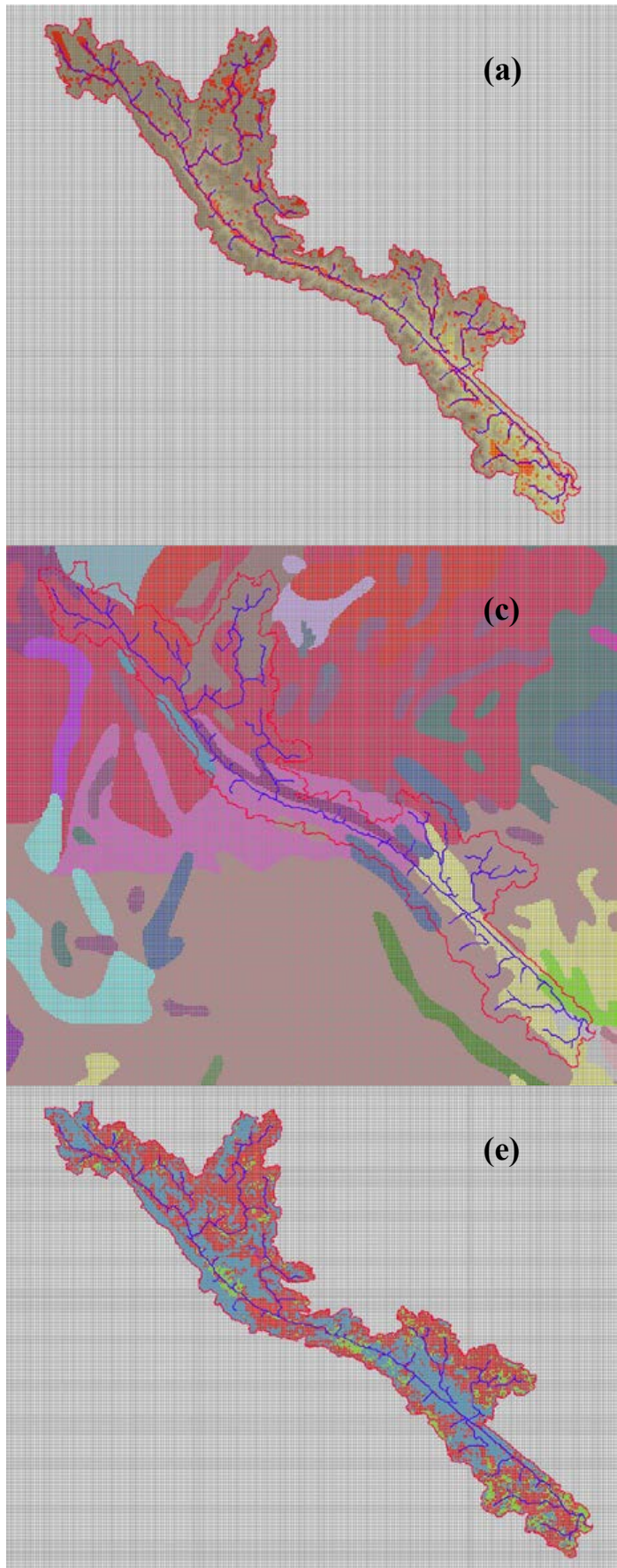

(nghĩa là lưới linh hoạt), đây chính là đặc điểm nổi bật và khác biệt của mô hình này với những mô hình hai chiều khác về việc tạo lưới tính toán mà thường là lưới chữ nhật hoặc lưới cong [16].

2.4 Thiết lập mô hình IFAS cho lưu vục sông Thao

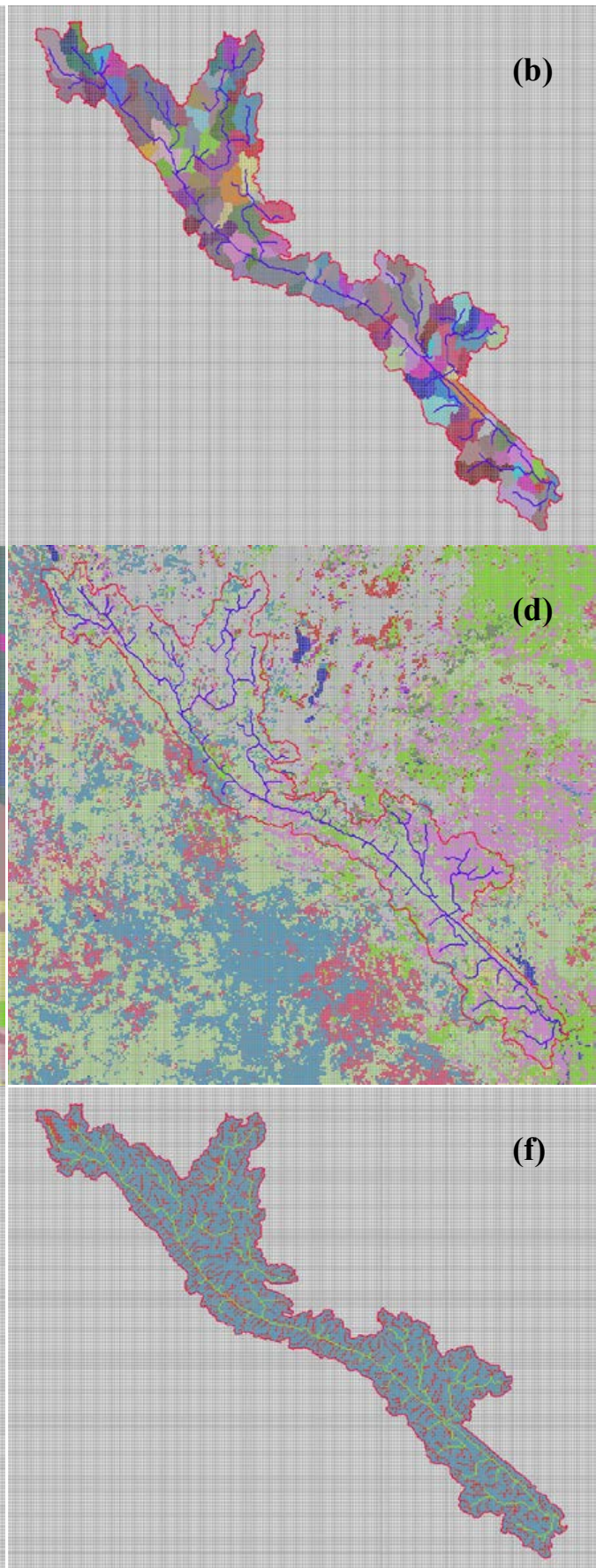

Hình 3. (a) Kết quả phân chia luu vưc; (b) Tiểu lưu vục sông Thao; (c) Số liệu địa chất; (d) Lớp phủ bề mặt lưu vục; (e) Thông số dòng chảy mặt (surface); (f) sông suối (river course) 
a) Thiết lập thông tin chung về luu vực cho mô hình IFAS

Do không có các số liệu địa hình, địa chất phần diện tích lưu vực nằm ở Trung Quốc nên trong nghiên cứu này sử dụng dữ liệu DEM ALOS độ phân giải $30 \mathrm{~m}$ và công cụ GIS phân chia lưu vực, phân chia sông suối thông qua mô đun Basin Data Manager; sử dụng số liệu lớp phủ bề mặt toàn cầu GLCC và bản đồ số dữ liệu đất DSMW để đưa vào mô hình IFAS (hình $3 \mathrm{a}-3 \mathrm{~d}$ ).

b) Thiết lập thông số mô hình IFAS cho luu vưc Nậm Nơn

Để đơn giản hóa mô hình cũng như tăng tốc độ chạy mô hình trong việc mô phỏng dòng chảy cho trận lũ có thời gian vài giờ hoặc vài ngày, nghiên cứu này lựa chọn mô hình bể chứa hai lớp. Với mô hình bể chứa hai lớp cần thiết lập thông số mô hình cho ba bộ thông số bao gồm lớp dòng chảy mặt, lớp dòng chảy tầng ngậm nước và lớp sông suối (hình $3 \mathrm{e}-3 \mathrm{f}$ ).

c) Thiết lập dũ liệu mura cho mô hình IFAS

Dữ liệu GSMAP được sử dụng trong nghiên cứu này là dữ liệu GSMAP_Gauge version 6 (Thuật toán GSMAP được nâng cấp lên phiên bản V6 vào tháng 9/2014). Dữ liệu mưa GSMAP_Gauge là sản phẩm được hiệu chỉnh số liệu GSMAP_MVK cùng với phân tích dữ liệu các trạm mưa toàn cầu được cung cấp bởi NOAA.

2.5 Thiết lập bộ mô hình mô phỏng ngập lụt khu vục thành phố Yên Bái thuộc lưu vục sông Thao

a) Thiết lập mô hình thủy lục 1 chiều MIKE11

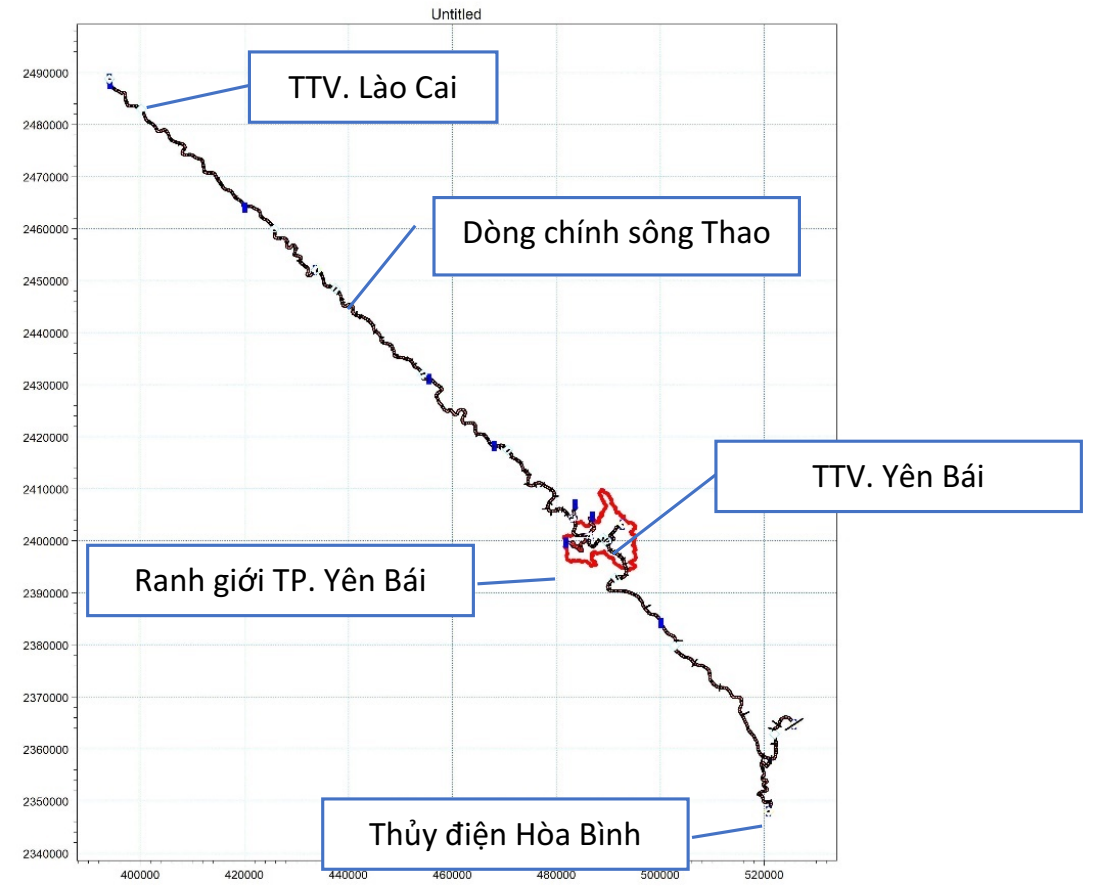

Hình 4. So đồ mạng sông tính toán thủy lực lưu vục sông Thao

Kết quả tính toán từ mô hình thủy văn IFAS sẽ là số liệu đầu vào cho mô hình thủy lực MIKE11. Để nghiên cứu rủi ro ngập lụt cho TP. Yên Bái, nghiên cứu này đã đưa vào mô phỏng dòng chính sông Thao và các sông nhánh đi qua TP. Yên Bái (hình 4).

* Bao gồm các trục sông lớn ảnh hưởng đến vùng nghiên cứu: (1) Sông Thao: Từ Lào Cai về Trung Hà, dài 260,138km (sử dụng 142 mặt cắt đo từ năm 2006-2012); (2) Sông Đà: Từ hạ lưu đập Hoà Bình đến cửa sông nhập vào sông Thao (Trung Hà), dài 60,7 km (sử dụng 49 mắt cắt đo năm 2008, 2012); (3) Sông Lô: Từ trạm thủy văn Vụ Quang đến cửa sông nhập vào sông Hồng, 
dài 50,93 km (sử dụng 55 mặt cắt đo năm 2012); (4) Sông Hồng: Từ Trung Hà đến Sơn Tây, dài 30,55 km (sử dụng 11 mặt cắt đo năm 2009).

Biên đầu vào lưu lượng các nhánh sông và biên nhập lưu khu giữa được sử dụng số liệu trích xuất từ mô hình thủy văn thông số phân bố IFAS và lưu lượng xả thực tế từ hồ Hòa Bình.

Biên dưới lấy số liệu mực nước thực đo tại trạm Phú Thọ.

* Các sông, suối nhỏ chảy qua thành phố Yên Bái: (1) Đoạn suối từ Yên Phúc đến Tuần Quán, dài $6.700 \mathrm{~m}$; (2) Đoạn suối Nam Cường: dài 5.700 m; (3) Đoạn suối Nga Quán dài 4.400 m; (4) Đoạn sông Âu Lâu dài 10.000 m (4 nhánh suối sử dụng 16 mặt cắt đo năm 2018).

b) Thiết lập mô hình thủy lực 2 chiều MIKE21

Dữ liệu về cao độ miền tính là cơ sở để mô hình mô phỏng các hướng chuyển động của dòng chảy cũng như các tương tác thủy lực của toàn bộ hệ thống. Cao độ của toàn bộ miền tính được khai thác từ cơ sở dữ liệu nền địa lý và bản đồ địa hình các tỷ lệ $1 / 2.000,1 / 10.000$ bao gồm đường đồng mức và điểm độ cao. Các loại dữ liệu về cao độ trên được trích xuất thành dạng XYZ (tọa độ theo phương $X$, tọa độ theo phương $Y$ và cao độ Z) trong hệ tọa độ WGS-1984. Với nguồn dữ liệu bản đồ có tỷ lệ lớn như trên, số điểm XYZ (Scatter Data) sau khi trích xuất là hơn 3 triệu điểm. Như vậy, mức độ chi tiết của dữ liệu về cao độ, đảm bảo cho việc mô phỏng chính xác địa hình của toàn bộ miền tính. Lưới sử dụng trong mô hình là lưới tam giác, chia ra 2 khu vực với độ chi tiết khác nhau, khu vực ven sông là khu vực chính mô phỏng dòng chảy lũ từ sông vào trong nội đồng được thiết lập chi tiết hơn với diện tích ô lưới lớn nhất là $400 \mathrm{~m}^{2}$ còn khu vực có địa hình cao hơn sát với đồi núi thì ô lưới thưa hơn với diện tích ô lưới lớn nhất là $1.000 \mathrm{~m}^{2}$. Trong mô hình MIKE 21 tiến hành thiết lập và mô phỏng hệ thống đê điều cũng như các tuyến đường giao thông chính trong vùng nghiên cứu thông qua mô đun công trình (Structures) (Hình 5). Trong phạm vi nghiên cứu đưa vào 12 tuyến đường và đê chính trong khu vực phạm vi thành phố Yên Bái và khu đông dân cư lân cận.

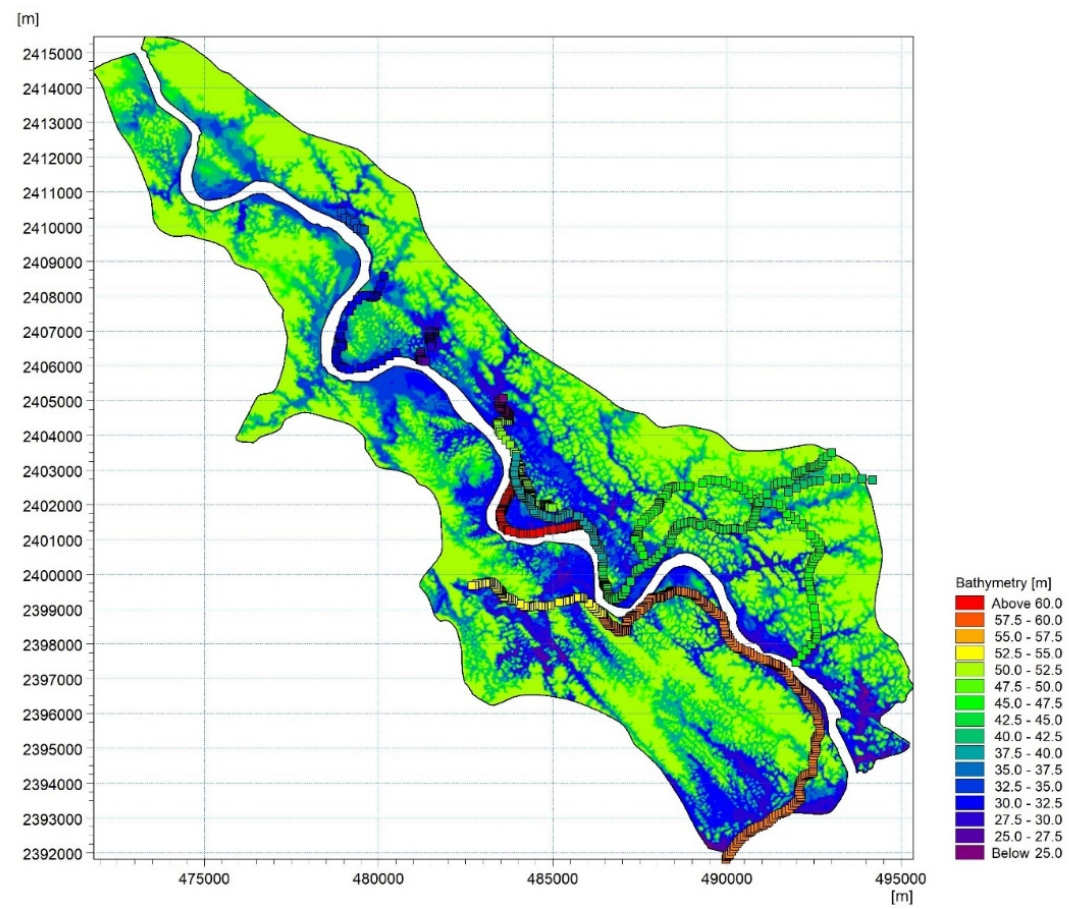

Hình 5. Thiết lập luới tính toán và công trình trong mô hình MIKE21

c) Thiết lập liên kết mô hình MIKE11 và MIKE21

Liên kết giữa mô hình MIKE11 và MIKE21 được thiết lập bằng hệ thống các liên kết bên tả và bên hữu từ mạng sông trong MIKE 11 đến miền tính của MIKE 21. Đối với các kịch bản tính toán, khi mực nước trong lòng sông của mô hình MIKE 11 vượt quá cao độ bờ sông tại một 
điểm bất kỳ thì nước sẽ tràn vào bãi (khu vực thuộc phạm vi tính toán của mô hình MIKE 21). Liên kết giữa mô hình MIKE11 và MIKE21 trong nghiên cứu này có tổng số 4 đoạn liên kết cho 2 đoạn sông, đoạn đầu sông Thao từ huyện
Trấn Yên đến trung tâm TP. Yên Bái; đoạn 2 sông Thao từ TP. Yên Bái đến kết thúc đoạn sông Thao nằm giáp ranh giữa huyện Trấn Yên và TP. Yên Bái (Hình 6).

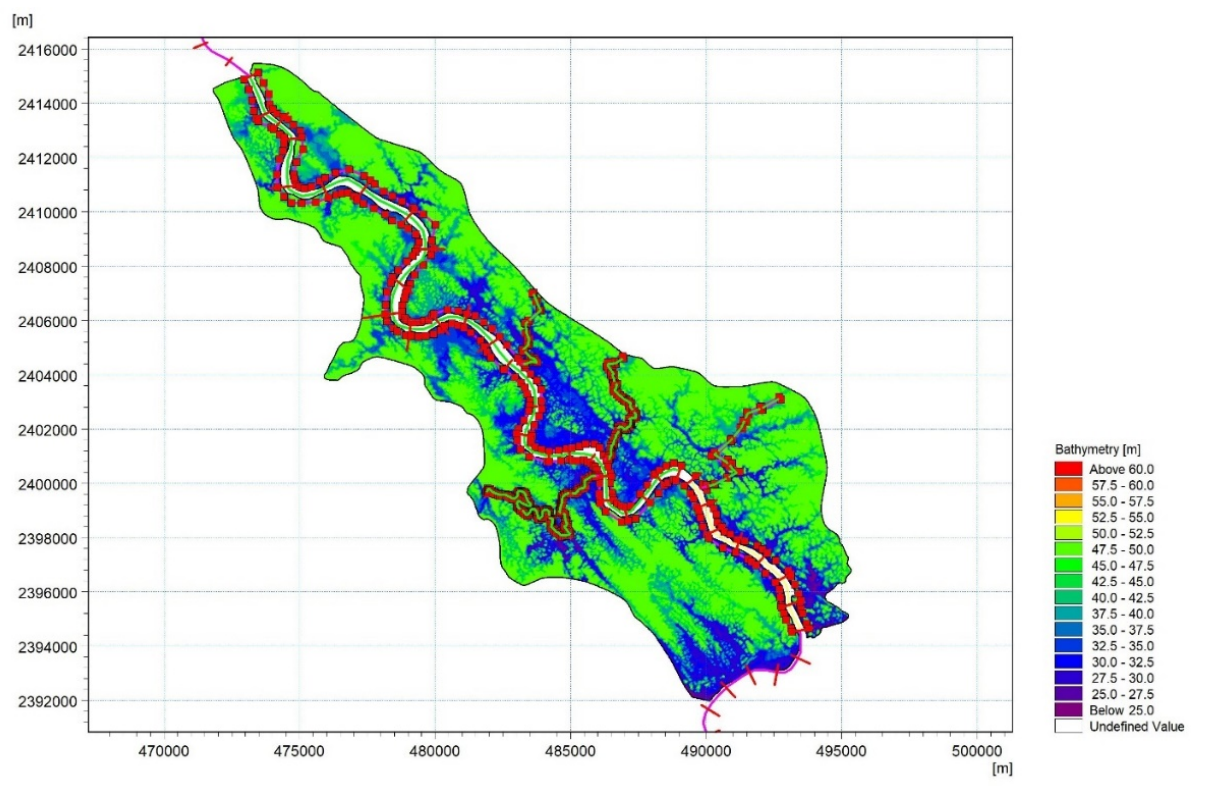

Hình 6. Mô phỏng kết nối giữa mô hình 1 chiều MIKE 11 và mô hình MIKE21

\section{Kết quả và thảo luận}

\subsection{Kết quả hiệu chỉnh và kiểm định mô} hình IFAS

a) Kết quả hiệu chỉnh mô hình IFAS

Thiết lập mô hình với trận lũ tháng 8/2008, số liệu lũ đã được mô phỏng và hiệu chỉnh các thông số mô hình và số liệu mưa. Kết quả mô phỏng và hiệu chỉnh trận lũ tháng 8/2008 tại trạm thủy văn Yên Bái được thể hiện trên hình 7.

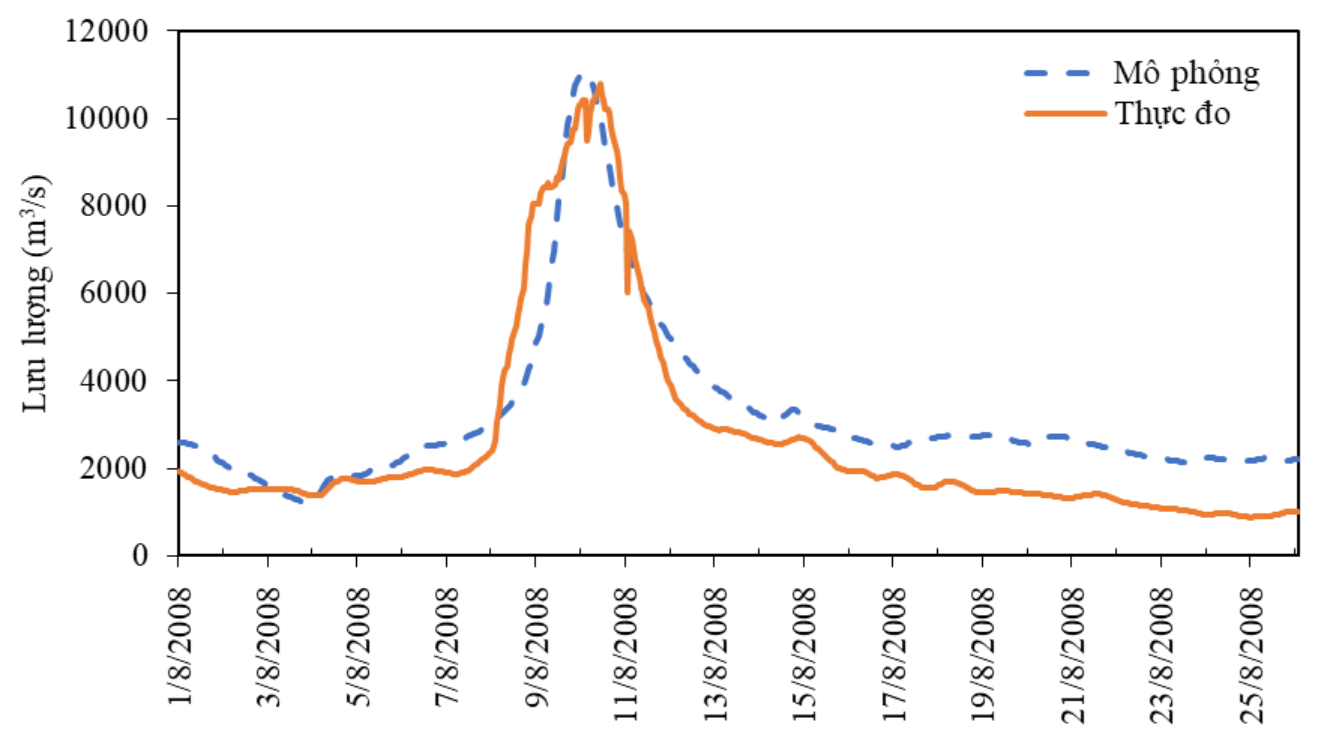

Hình 7. So sánh lưu lượng lũ tại Yên Bái mô phỏng và thực đo trận lũ tháng 8/2008 


\section{BÀI BÁO KHOA HỌC}

Qua kết quả tính toán tương quan giá trị lưu lượng max $\mathrm{Q}_{\max }\left(\mathrm{m}^{3} / \mathrm{s}\right)$ từng giờ tại Yên Bái mô phỏng và thực đo trận lũ tháng $8 / 2008$, có thể thấy hệ số tương quan $\mathrm{R}^{2}=0,887$. Ngoài ra để đánh giá kết quả mô phỏng và hiệu chỉnh mô hình IFAS với trận lũ tháng 8/2008 tại Yên Bái, tiến hành tính toán hệ số Nash-Sutcliffe (NSE) đạt được tại Yên Bái là NSE $=0,813$.

\section{b) Kết quả kiểm định mô hình IFAS}

Để đánh giá tính chính xác của mô hình IFAS, đã tiến hành kiểm định lại mô hình với trận lũ tháng 8/2016. Kết quả kiểm định mô hình được thể hiện trên hình 8 .

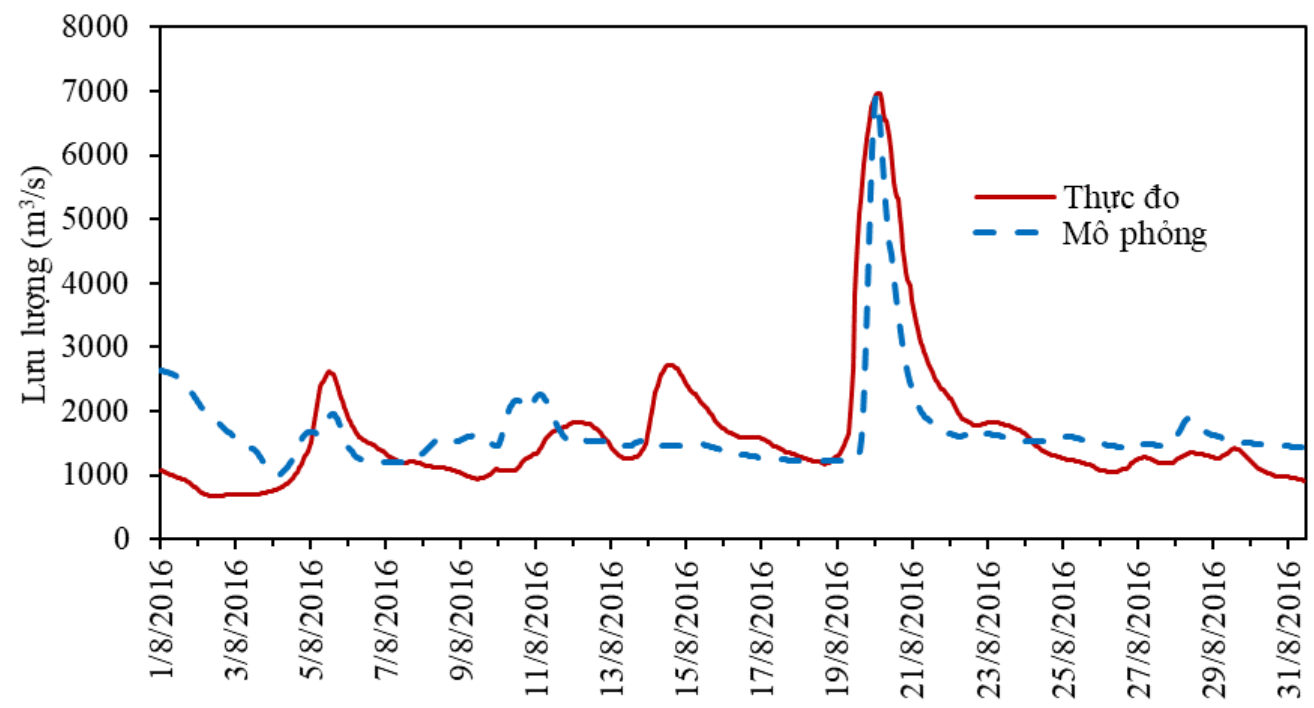

Hình 8. So sánh luu luợng lũ tại Yên Bái mô phỏng và thục đo trận lũ tháng 8/2016

Qua kết quả tính toán tương quan giá trị lưu lượng $\max \mathrm{Q}_{\max }\left(\mathrm{m}^{3} / \mathrm{s}\right)$ từng giờ tại Yên Bái mô phỏng và thực đo trận lũ tháng $8 / 2016$, có thể thấy hệ số tương quan $\mathrm{R}^{2}=0,555$. Ngoài ra để đánh giá kết quả kiểm định mô hình IFAS với trận lũ tháng 8/2016 tại Yên Bái, tiến hành tính toán hệ số Nash-Sutcliffe (NSE) đạt được tại Yên Bái là $\mathrm{NSE}=0,547$.

\subsection{Kết quả mô phỏng ngập lụt TP. Yên Bái} và khu đông dân cu lân cận

a) Kết quả hiệu chỉnh bộ mô hình mô phỏng ngập lụt với trận lũ tháng $8 / 2008$

Sau khi quá trình tính toán hiệu chỉnh các thông số của mô hình thuỷ lực đã nhận được kết quả mực nước, lưu lượng tại các vị trí trạm thuỷ văn khá phù hợp với giá trị thực đo. Mực nước lũ lớn nhất tại các vị trí kiểm tra trên toàn mạng sông được thể hiện trên bảng 2.

Kết quả tính toán mô phỏng trận lũ tháng
8/2008 cho thấy sai số giữa tính toán và đo đạc là 0,03 đến $-0,083 \mathrm{~m}$. Mặt khác toàn bộ đường quá trình mực nước, lưu lượng tại từng vị trí có dạng đường lũ lên và xuống phù hợp và bám sát với nhau. Kết quả tính hệ số tương quan $\mathrm{R}^{2}=$ 0,875 . Với bộ thông số mô hình này đảm bảo độ tin cậy và sử dụng trong khai thác các phương án lũ đối với hệ thống sông Thao đặc biệt mô phỏng chế độ ngập lụt cho thành phố Yên Bái. Các bản vẽ đường quá trình mực nước, lưu lượng thực đo và kết quả tính toán hiệu chỉnh của mô hình thuỷ lực được trình bày trong hình 9 .

Bảng 2. Mực nuơóc lớn nhất thực đo và mô phỏng tại các vị trí trận lũ 8/2008

\begin{tabular}{llllll}
\hline \multirow{2}{*}{ TT } & Trạm & Sông & \multicolumn{2}{l}{$\mathrm{H}_{\max }(\mathrm{m})$} & Thực \\
\cline { 3 - 5 } & & $\begin{array}{l}\text { Tính } \\
\text { đo }\end{array}$ & toán & $(\mathrm{m})$ \\
\hline 1 & Bảo Hà & Thao & 60,93 & 60,90 & 0,03 \\
2 & Yên Bái & Thao & 34,23 & 34,31 & $-0,08$ \\
\hline
\end{tabular}



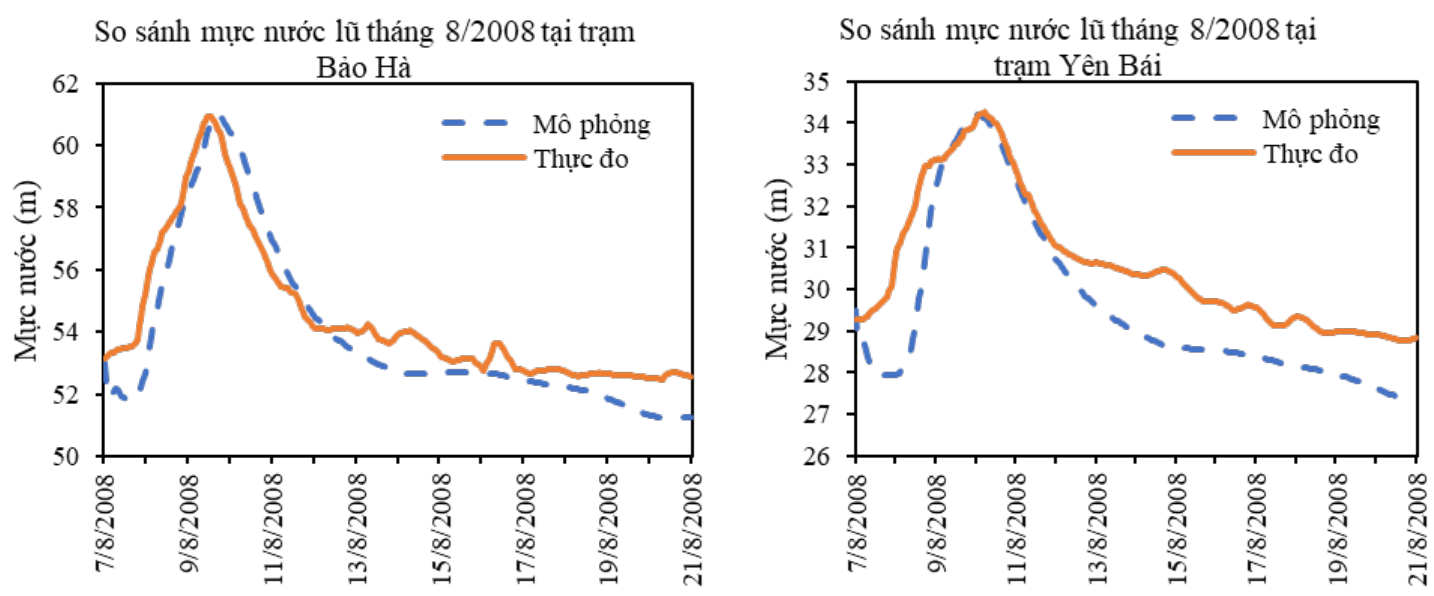

Hình 9. So sánh đường quá trình mực nước lũ tháng 8/2008 tại Bảo Hà và Yên Bái giữa thực đo và mô phỏng

b) Kết quả kiểm định bộ mô hình mô phỏng ngập lụt trận lũ tháng $8 / 2016$

Để đảm bảo tính chính xác của bộ mô hình thủy lực mô phỏng lũ trên lưu vực sông Thao, việc kiểm định lại việc mô phỏng của mô hình với 1 trận lũ khác là cần thiết. Trên cơ sở bộ thông số đã xác định được trong quá trình tính toán mô phỏng trận lũ thực tế tháng $8 / 2008$, chúng tôi tiến hành tính toán kiểm định mô hình với trận lũ thực tế đã xảy ra tháng 8/2016. Bảng 3 là mực nước lũ lớn nhất giữa kết quả tính toán và thực đo tại trạm thủy văn Bảo Hà và Yên Bái.

Bảng 3. Mực nước lớn nhất thực đo và mô phỏng tại các vị trí trận lũ 8/2016

\begin{tabular}{|c|c|c|c|c|c|}
\hline \multirow[b]{2}{*}{ TT } & \multirow[b]{2}{*}{ Trạm } & \multirow[b]{2}{*}{ Sông } & \multicolumn{2}{|c|}{$\mathrm{H}_{\max }(\mathrm{m})$} & \multirow{2}{*}{$\begin{array}{l}\text { - Sai số } \\
\text { (m) }\end{array}$} \\
\hline & & & $\begin{array}{l}\text { Thực } \\
\text { đo }\end{array}$ & $\begin{array}{l}\text { Tính } \\
\text { toán }\end{array}$ & \\
\hline 1 & Bảo Hà & Thao & 57,83 & 57,91 & $-0,08$ \\
\hline 2 & Yên Bái & Thao & 32,88 & 32,81 & 0,07 \\
\hline
\end{tabular}

Kết quả tính toán mô phỏng trận lũ tháng $8 / 2016$ cho thấy sai số giữa tính toán và đo đạc là $-0,08$ đến $0,07 \mathrm{~m}$. Mặt khác toàn bộ đường quá trình mực nước, lưu lượng tại từng vị trí có dạng đường lũ lên và xuống phù hợp và bám sát với nhau. Hệ số tương quan $\mathrm{R}^{2}$ giữa mô phỏng và thực đo là 0,624 . Với việc kiểm định lại bộ thông số mô hình lũ tháng 8/2008 với trận lũ tháng $8 / 2016$, kết quả chỉ ra rằng bộ thông số mô hình này đảm bảo độ tin cậy và sử dụng trong khai thác các phương án lũ đối với hệ thống sông Thao đặc biệt mô phỏng chế độ ngập lụt cho thành phố Yên Bái. Các bản vẽ đường quá trình mực nước, lưu lượng thực đo và kết quả tính toán kiểm định của mô hình thuỷ lực với trận lũ tháng 8/2016 được trình bày trong hình 10 .

c) Kết quả mô phỏng quá trình ngập lụt TP. Yên Bái trận lũ lịch sủ

Trong nghiên cứu này, bộ thông số mô hình thủy văn (IFAS) và bộ thông số mô hình mô phỏng ngập lụt (MIKE11, MIKE21) được đánh giá là tốt đối với cả hai quá trình hiệu chỉnh và kiểm định mô hình. Nghiên cứu đã sử dụng số liệu trận lũ xảy ra tháng 8/2008 và tháng $8 / 2016$ để mô phỏng diễn biến ngập lụt cho khu vực thành phố Yên Bái và khu vực đông dân cư lân cận (hình 11). Kết quả thống kê diện tích ngập, mức độ ngập khu vực TP. Yên Bái và khu đông dân cư ven sông Thao từ mô hình như trong bảng 4 dưới đây. 

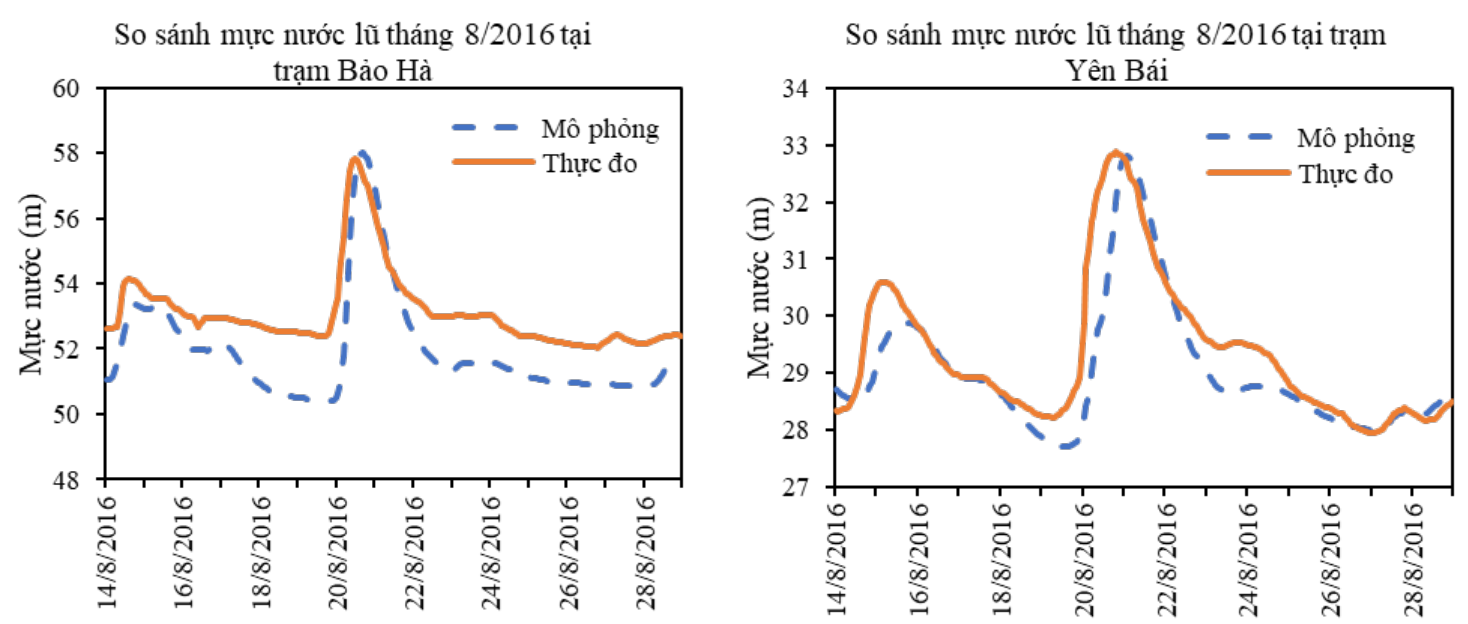

Hình 10. So sánh đưòng quá trình mục nước lũ tháng 8/2016 tại Bảo Hà và Yên Bái giũua thực đo và mô phỏng

Bảng 4. Thống kê diện tích và mức độ ngập khu vục TP. Yên Bái và vùng đông dân cư ven sông Thao

\begin{tabular}{|c|c|c|c|c|c|c|c|c|c|c|c|c|}
\hline \multirow{2}{*}{ Kịch bản } & \multirow{2}{*}{ Huyện, thành phố } & \multirow{2}{*}{$\begin{array}{c}\text { F ngập } \\
\text { (ha) }\end{array}$} & \multicolumn{10}{|c|}{ Diện tích ngập phân theo mức ngập (m) } \\
\hline & & & $0,1-0,5$ & $0,5-1$ & $1-1,5$ & $\dot{1,5-2}$ & $2-2,5$ & $2,5-3$ & $3-3,5$ & $3,5-4$ & $4-4,5$ & $>4,5$ \\
\hline Lũ tháng & TP. Yên Bái & 1233,7 & 43,3 & 65,7 & 82,8 & 134,9 & 94,4 & 119,9 & 119,4 & 132,3 & 152,6 & 288,5 \\
\hline $8 / 2008$ & H. Trấn Yên & 805,6 & 41,2 & 62,8 & 50,1 & 51,5 & 102,6 & 72,0 & 65,1 & 68,5 & 70,5 & 221,5 \\
\hline Lũ tháng & TP. Yên Bái & 214,0 & 59,7 & 51,9 & 44,1 & 18,8 & 7,7 & 6,7 & 5,4 & 4,5 & 5,6 & 9,4 \\
\hline $8 / 2016$ & H. Trấn Yên & 204,4 & 41,4 & 53,9 & 60,9 & 31,0 & 13,3 & 3,4 & 0,6 & 0,0 & 0,0 & 0,0 \\
\hline
\end{tabular}

\section{Kết luận}

Nghiên cứu này đã sử dụng mô hình IFAS với số liệu đầu vào từ dữ liệu viễn thám để mô phỏng dòng chảy lũ cho lưu vực sông Thao có phần lớn diện tích lưu vực nằm ở Trung Quốc. Mô hình IFAS có ưu điểm là khả năng xử lý khối lượng lớn và đa đạng các nguồn dữ liệu viễn thám, đặc biệt là các dữ liệu mưa vệ tinh, thời gian tính toán mô phỏng nhanh. Các dữ liệu viễn thám được nghiên cứu sử dụng là số liệu mưa vệ tinh GSMAP và dữ liệu DEM ALOS.

Qua kết quả nghiên cứu mô phỏng và kiểm định các trận lũ trong những năm gần đây, trận lũ tháng 8/2008 và trận lũ tháng 8/2016 có thể thấy kết quả tương đối tốt khi so sánh giữa mô phỏng và thực đo thông qua việc đánh giá các hệ số $\mathrm{NASH}$ và hệ số tương quan $\mathrm{R}^{2}$. Cũng qua kết quả này, có thể kết luận được rằng, có thể sử dụng số liệu từ viễn thám kết hợp với việc ứng dụng mô hình thủy văn phân bố trong mô phỏng dòng chảy lũ cho lưu vực sông Thao.
Kết quả hiệu chỉnh mô hình mô phỏng ngập lụt TP. Yên Bái và khu đông dân cư ven sông Thao bằng cách liên kết mô hình thủy lực 1 chiều MIKE11 và mô hình thủy lực 2 chiều MIKE21 cho kết quả với trận lũ tháng 8/2008 hệ số $\mathrm{R}^{2}$ tại Yên Bái đạt 0,875 ; hiệu chỉnh với trận lũ 8/2016 hệ số $\mathrm{R}^{2}$ tại Yên Bái đạt 0,624 . Nghiên cứu cũng xây dựng bản đồ vùng nguy cơ ngập lụt tương ứng với kịch bản lũ lịch sử năm 2008 và 2016.

Việc mô phỏng được một cách khá tốt dòng chảy lũ trên lưu vực sông Thao là tiền đề để nghiên cứu công tác dự báo lũ, qua việc kết hợp sử dụng số liệu từ dữ liệu mưa vệ tinh toàn cầu và sử dụng số liệu mưa dự báo từ các mô hình dự báo toàn cầu, cùng với sử dụng mô hình IFAS để dự báo lũ cho hạ du sông Thao, nhằm phòng chống và giảm thiểu tác hại của lũ gây ra cho kinh tế - xã hội , đặc biệt khu vực dân cư tập trung ven sông Thao. Kiến nghị, các nội dung này sẽ được nghiên cứu trong giai đoạn tiếp theo. 

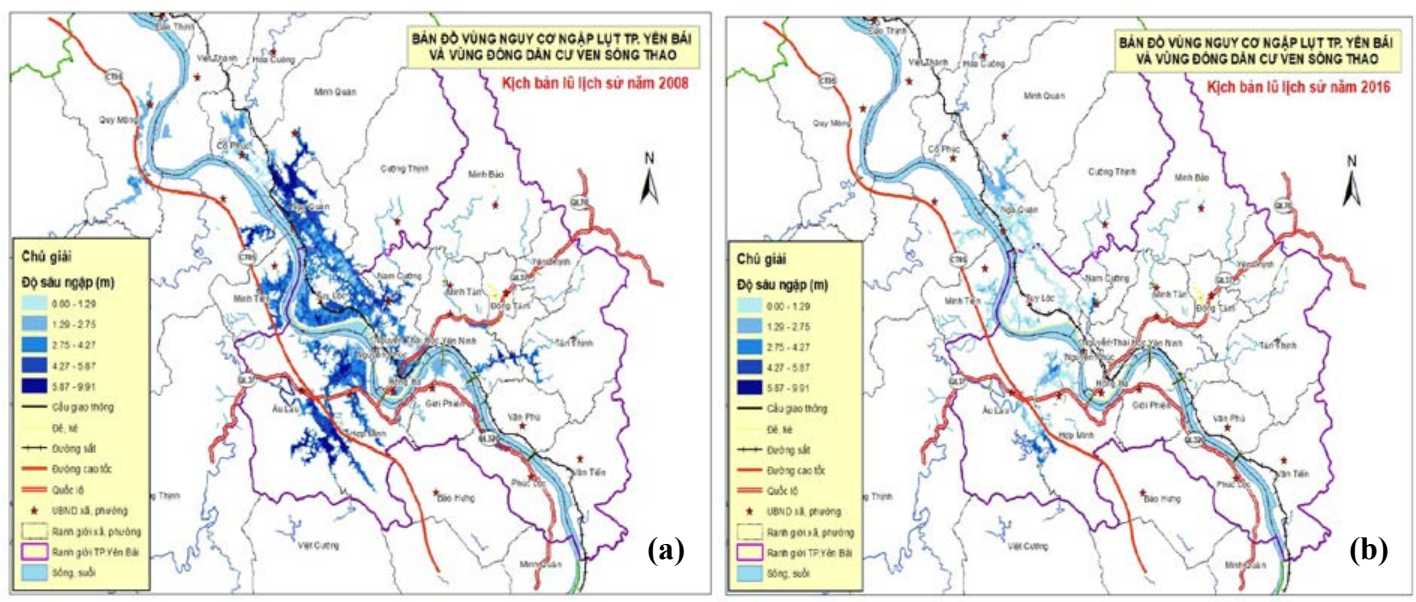

Hình 11. Bản đồ mô phỏng ngập lụt trận lũ năm 2008, 2016

Lời cảm ơn: Nghiên cưu này là một phần kết quả của đề tài nghiên cứu khoa học và phát triển công nghệ cấp Quốc gia "Nghiên cứu đánh giá rủi ro lũ, ngập lụt và đề xuất các giải pháp phòng tránh, thich ưng cho các khu vực tập trung đông dân cu, đô thị vùng miền núi Bắc Bộ", Mã số: KC08.26/16-20.

\section{Tài liệu tham khảo}

1. Bates, P.D. (2004), Remote sensing and flood inundation modelling. Hydrological Processes, $18,2593-2597$.

2. Bates, P.D. (2012), Integrating remote sensing data with flood inundation models: how far have we got?. Hydrological Processes, 26, 2515-2521.

3. Klemas, V. (2015), Remote Sensing of Floods and Flood-Prone Areas: An Overview. Journal of Coastal Research, 31 (4), 1005-1013.

4. Viện Quy hoạch Thủy lợi (2018), Rà soát Quy hoạch Thủy lợi lưu vực sông Đà Thao giai đoạn đến năm 2025, tầm nhìn 2030.

5. Đoàn Quang Trí (2019), Úng dụng mô hình thủy văn - thủy lục kết hợp dụ báo mưa IFS phục vu cảnh báo lũ, ngập lụt hạ lưu sông Vu Gia - Thu Bồn. Tạp chí Khí tượng Thủy văn, 703, 27-41.

6. Trịnh Minh Ngọc (2009), Úng dụng mô hình SWAT tính toán kéo dài số liệu dòng chảy lưu vực sông Luc Nam, Tạp chí khoa học Đại học Quốc gia Hà Nội. Khoa học Tự nhiên và Công nghệ, 25 (3S), 484-491.

7. Nguyễn Ý Như và Nguyễn Thanh Sơn (2009), Úng dụng mô hình SWAT khảo sát ảnh hưởng của các kịch bản sử dụng đất đối với dòng chảy lưu vực sông Bến Hải, Tạp chí khoa học Đại học Quốc gia Hà Nội. Khoa học Tự nhiên và Công nghệ, 25 (3S), 492-498.

8. Le Viet Son, Luong Ngoc Chung, Bui Tuan Hai, Sai Hong Anh and Nguyen Duy Quang (2019), Assessing Satellite-Based Precipitation Products to Create Flood Forecasting in the Da River Basin, Vietnam. Journal of Geoscience and Environment Protection, 7 (11), 113-123.

9. Bùi Tuấn Hải và Lê Quang Vinh, Nghiên cưu ứng dụng kết hợp dũ liệu viến thám và mô hình toán IFAS trong mô phỏng dòng chảy lũ luu vực sông Nậm Non thuộc hệ thống sông Cả. Tạp chí Nông nghiệp \& Phát triển nông thôn, 369 (18), 96-101.

10. Đỗ Cao Đàm, Trịnh Quang Hòa, Hà Văn Khối, Đoàn Trung Lưu, Nguyễn Năng Minh, Lê Đình Thành, Dương Văn Tiển (1993), Thủy văn công trình, Nhà xuất bản Nông nghiệp, Hà Nội.

11. Ngô Đình Tuấn (1998), Phân tích thống kê trong thủy văn, Nhà xuất bản Nông nghiệp, Hà Nội. 


\title{
BÀI BÁO KHOA HỌC
}

12. Bùi Tuấn Hải, Nguyễn Văn Tuấn (2018), Nghiên cưu đánh giá vá so sánh các dĩ liệu mưa vệ tinh độ phân giải cao luu vục sông Cả. Tạp chí Khí Tượng Thủy văn, 695, 17-28.

13. Bùi Tuấn Hải, Vương Tấn Công, Phạm Quang Vinh (2019), So sánh, đánh giá các dũ liệu mô hình số độ cao (DEM) trên lưu vực sông Cả. Kỷ yếu Hội nghị Khoa học Địa lý toàn quốc lần thứ XI năm 2019, Thừa Thiên Huế, 2019.

14. International Centre for Water Hazard and Risk Management (2018), IFAS ver.2.0 technical manual.

15. MIKE by DHI (2011), MIKE11 - A modelling system for Rivers and Channels - User Guide.

16. MIKE by DHI (2011), MIKE21\&MIKE3 FLOW MODEL FM - Hydrodynamic and Transport Module Scientific Documentation.

\section{RESEARCH ON THE APPLICATION OF IFAS MODEL AND RE- MOTE SENSING DATA IN SIMULATING CROSS-BORDER FLOOD FLOWS IN THAO RIVER BASIN}

\section{Bui Tuan Hai ${ }^{1}$, Le Viet Son ${ }^{1}$}

${ }^{1}$ Institute of Water Resources Planning

\begin{abstract}
This study applied the combination of remote sensing data and IFAS model in crossborder flood flow simulation of Thao river basin with most of the basin located in China. The results of modification and calibration of IFAS model for the floods in 2008 and 2016 indicated that the model with remote sensing input data is capable of simulating flood flows quite well. Adjusted results of IFAS model of August flood for the correlation coefficient $R^{2}=0.887$, NSE coefficient $=$ 0.813; Test results with the August 2016 flood for the coefficient $R^{2}=0.555$ and the NSE coefficient $=0.547$. Modification results of flood simulation model Yen Bai city and densely populated areas along Thao river by linking one-way hydraulic model MIKE11 and two-way hydraulic model MIKE21 show results in August 2008 flood, $R^{2}$ coefficient in Yen Bai reached 0.875; the results of calibration with the August 2016 flood, the $R^{2}$ coefficient in Yen Bai reached 0.624. The study also developed a map of flood risk areas corresponding to historical flood scenarios in 2008 and 2016. The good simulation of flood flow in the Thao River basin is a premise to forecast floods for the downstream Thao River, in order to prevent and minimize the harmful effects offloods on socio-economic situation, especially densely populated area along Thao River.
\end{abstract}

Keywords: Thao River basin, Remote sensing, IFAS, GSMAP, MIKE11, MIKE21. 